\title{
AS RESTRIÇÕES AO EXERCÍCIO ABUSIVO DA ADMINISTRAÇÃO DAS SOCIEDADES LIMITADAS COMO FORMA DE PROTEÇÃO AOS SÓCIOS MINORITÁRIOS
}

\section{THE RESTRICTIONS TO THE IMPROPER USE OF LIABILITY COMPANY'S ADMINISTRATION AS A WAY OF SHAREHOLDER'S PROTECTION}

\section{RESUMO}

\author{
${ }^{1}$ João Luis Nogueira Matias \\ ${ }^{2}$ Cristiane Pinheiro Diógenes
}

A sociedade limitada prevista no Código Civil, em sintonia com os princípios decorrentes da Constituição Federal, deixou de ser tratada como assunto exclusivo dos sócios, com o reconhecimento de interesses a si alheios. Novos padrões são definidos nas relações internas, com a proteção dos direitos dos minoritários. Há o reconhecimento da liberdade dos sócios moldarem a administração da sociedade limitada, contudo, também são postas normas cogentes que limitam o exercício abusivo da administração. Analisa-se a tipologia da administração; a profissionalização da administração e os conflitos de agência; os conflitos de interesses entre a administração e a sociedade e a fiscalização dos atos de administração. Constata-se que as restrições à administração configuram proteção aos sócios minoritários.

PALAVRAS CHAVE: Administração da sociedade limitada; Proteção aos sócios minoritários; Governo de empresas; Conflitos de agência; Conflitos de interesse

\begin{abstract}
The brazilian limited company, in line with the principles of the Constitution, is not treated as partners's subject. There is the recognition of outside's interest. New standards are set in the internal relations with the protection of the rights of the minority. The partners can shape the limited company governance, however, the brazilian civil code put cogent norms that limit the abuse of management. In this paper will be analyzed the administration typology; agency conflicts; conflicts of interests between direction and the limited company and the management control. It is verified that the restrictions on brazilian limited company administration provides protection to shareholders.
\end{abstract}

KEYWORDS: Brazilian limited company; Shareholders protection; Corporate governance; Agency conflicts; Conflicts of interests

\footnotetext{
${ }^{1}$ Professor do Programa de Pós-Graduação da Faculdade de Direito da Universidade Federal do Ceará UFC, Ceará, CE e do Centro Universitário 7 de Setembro - UNI7, Ceário, CE, (Brasil). Pós-Doutor em Direito Econômico pela Faculdade de Direito da Universidade de Lisboa. Doutor em Direito Comercial pela Faculdade de Direito da Universidade de São Paulo. Doutor em Direito Público pela Faculdade de Direito do Recife da Universidade de Pernambuco - UFPE, Pernambuco, PE, (Brasil). Coordenador do Projeto de Pesquisa "Os impactos da proteção ao meio ambiente no direito: Novos paradigmas para o direito privado", CNPq/CAPES/UFC. Juiz Federal, (Brasil). E-mail: joaoluisnm@uol.com.br.

2 Advogada e mestranda do Curso de Mestrado do Programa de Pós-graduação em Direito do Centro Universitário 7 de Setembro - UNI7, Ceário, CE, (Brasil). E-mail:
} cristianediogenes@diogenesadv.com.br. 


\section{INTRODUÇÃO}

A sociedade limitada é pessoa jurídica e, como tal, sujeito de direitos e de obrigações. Ao exercer seus direitos e cumprir seus deveres, pratica atos e, na lição de Pontes de Miranda, "quem pratica os seus atos é o órgão, ou são os órgãos, se em caso de distribuição de funções; porque os órgãos são parte dela como o braço, a boca e o ouvido são órgãos da pessoa física". ${ }^{3}$

Os administradores são os órgãos da sociedade limitada. ${ }^{4}$ É por seu intermédio que a sociedade manifesta a sua vontade, sendo certo que os administradores não agem em nome da sociedade, mas expressam a sua vontade..$^{5}$

No regime do Decreto 3.798/19, a sociedade limitada era regida pelo princípio da autoorganicidade, através do qual a gestão da empresa era reservada, de forma exclusiva, aos sócios, o que era decorrência da combinação dos artigos $2^{\circ}$, do Decreto 3.708/19 com o número 03, do artigo 302, do Código Comercial, o que levou Cunha Peixoto a afastar qualquer dúvida sobre a intenção do legislador, que ao longo de toda a lei faz expressa referência a expressão "sócio-gerente". 67

${ }^{3}$ PONTES DE MIRANDA, Francisco Cavalcante. Tratado de direito privado. 3. ed. Rio de Janeiro: Borsoi, 1977. v.10 e 49. t. I, p.282.

${ }^{4}$ ABRÃO, Nelson. Sociedade por quotas de responsabilidade limitada. 6. ed. Atualizada por Carlos Henrique Abrão. São Paulo: Revista dos Tribunais, 1988, p.121-122.

${ }^{5}$ Sobre a relação da sociedade com os administradores, a lição é de Carlos Fulgêncio Cunha Peixoto que afasta a idéia de atuação por mandato. A sociedade por quotas de responsabilidade limitada: doutrina, jurisprudência, legislação e prática. Rio de Janeiro: Forense, 1956. v.I., p.286-291: "E sobre a relação jurídica entre os diretores, ou gerentes, com a sociedade, divergem os autores, parecendo a uns, tratar-se de simples mandato, enquanto outros aí vêem mera locação de serviços. Afinal, e segundo a teoria de Gierke, ainda há quem sustente serem os administradores um órgão permanente e essencial de sociedade, órgão que se apresenta revestido dos poderes necessários para agir por ela, tanto interna, como externamente. [...] Pela maneira por que se define, o mandato menos se ajusta aos administradores das sociedades, pois se com ele é que uma pessoa pratica um ato jurídico em nome de outra, há, aí a existência de duas pessoas distintas: o representante e o representado. Ora, os administradores não agem em nome da sociedade, mas apenas por intermédio seu é que ela manifesta a sua vontade". Egberto Lacerda Teixeira, também era defensor da mesma argumentação: "A natureza jurídica dessa representação já foi objeto de largos e intermináveis debates, prevalecendo, no passado, a idéia privatística de que os administradores seriam meros mandatários da sociedade, ou mesmo, dos sócios. $\mathrm{O}$ desenvolvimento da noção de empresa, a concepção institucional das sociedades mercantis, preferentemente as anônimas, contribuíram eficazmente para o repúdio da solução contratualista. Professa-se, hoje em dia, a convicção de que os diretores, gerentes ou administradores das sociedades de índole capitalista são, na verdade, órgãos da sociedade". TEIXEIRA, Egberto Lacerda. Das sociedades por quotas de responsabilidade limitada. Atualizado de acordo com o novo Código Civil por Silas Tozzini e, Renato Berger. São Paulo: Quartier Latin, 2006, p.105.

${ }^{6}$ Artigo $2^{\circ}$, do Decreto 3.708/19: O título constitutivo regular-se-á pelas disposições dos artigos 300 a 302 e seus números do Código Comercial, devendo estipular ser limitada a responsabilidade dos sócios á importância total do capital social. "Artigo 302 do Código Comercial: [...] 3. Os nomes dos sócios que podem usar da firma social ou gerir em nome da sociedade; na falta desta declaração, entende-se que todos os sócios podem usar da firma social e gerir em nome da sociedade."

${ }^{7}$ PEIXOTO, Carlos Fulgêncio Cunha, op. cit., 1956. v.I, p.290, na linguagem original: "Para não deixar dúvida de que êsse dispositivo se aplica à sociedade por cota de responsabilidade limitada, o Decreto 3.708/19, além de estipular que o título constitutivo desta sociedade se regulará pelas disposições dos

Revista Brasileira de Direito Empresarial -le-SSN: 2526-0235| Curitiba | v. 2 | n. 2 | p. 24 - 41 | Jul/Dez. 2016. 
Proibida a gestão por não sócios, facultava o Decreto a delegação dos poderes de gerência, desde que no contrato social não constasse cláusula proibitiva de que ela ocorresse, na forma do que era previsto em seu artigo $13 .^{8}$

As regras do regime anterior eram evidência clara da prevalência do perfil personalista da sociedade limitada, tratada como assunto exclusivo dos sócios, o que somente foi modificado, em parte, com o advento do Código Civil de 2002, que permite a administração da sociedade por terceiros alheios ao quadro societário, na forma do artigo $1061 .^{9}$

No Código Civil é previsto que a sociedade limitada seja administrada por uma ou mais pessoas designadas no contrato social ou em ato separado, sendo permitida a ampla regulação da matéria pelos sócios, a demonstrar a permanência de critérios contratualistas, havendo extrema flexibilidade para organizar-se a administração da sociedade limitada, que pode ter apenas um administrador ou, até mesmo, ter órgãos de deliberação colegiada, como é típico das companhias. ${ }^{10}$

No exercício da liberdade que lhes foi outorgada, compete aos sócios deliberarem sobre o modelo de administração pretendido devendo, contudo, obedecer as normas cogentes fixadas pelo legislador.

Tem-se por objetivo a demonstração de que a fixação de normas cogentes promove a proteção dos sócios minoritários, evitando que fiquem vinculados à vontade exclusiva dos majoritários.

Inicialmente, serão analisados alguns aspectos da tipologia da sociedade limitada. Em seguida, a abordagem versará sobre a profissionalização da gestão e os conflitos de agência e sobre o conflito de interesse entre a sociedade e os administradores. Após, a discussão abordará a fiscalização da administração. Ao final, serão apresentadas as conclusões.

artigos 300 a 302 do Código Comercial, usa sempre a expressão "sócio-gerente", todas as vezes em que se refere à administração".

8 "Artigo 13 - O uso da firma cabe aos sócios-gerentes; se, porém, for omisso o contrato todos os sócios dela poderão usar. É lícito aos gerentes delegar o uso da firma somente quando o contrato não contiver cláusula que se oponha a essa delegação. Tal delegação, contra disposição do contrato, dá ao sócio que a fizer pessoalmente a responsabilidade das obrigações contraídas pelo substituto, sem que possa reclamar da sociedade mais do quem sua parte das vantagens auferidas do negócio."

9 "Artigo 1061 - Se o contrato permitir administradores não sócios, a designação deles dependerá de aprovação da unanimidade dos sócios, enquanto o capital não estiver integralizado, e de dois terços, no mínimo, após a integralização".

${ }^{10}$ GONÇALVES NETO, Alfredo de Assis. Direito de empresa - comentários aos artigos 966 a 1.195 do Código Civil. São Paulo: Revista dos Tribunais, 2007, p.326. Em sentido contrário, defendendo que a tendência, "de lege ferenda, é a da atribuição da gerência somente a pessoas naturais". LUCENA, José Waldecy, op. cit., 2003, p.414-415.

Revista Brasileira de Direito Empresarial -le-SSN: 2526-0235| Curitiba | v. 2 | n. 2 | p. 24 -41 |

Jul/Dez. 2016. 


\section{A TIPOLOGIA DA ADMINISTRAÇÃO DA SOCIEDADE LIMITADA NO CÓDIGO CIVIL}

Tem-se por correto que os administradores não podem ser pessoas jurídicas, como proibição não decorre de texto expresso do Código Civil, ${ }^{11}$ o tema ainda desperte certa polêmica, ${ }^{12}$ sobretudo em razão do então consagrado entendimento jurisprudencial permissivo e pelo fato de que o Código Civil quando pretendeu vetar a administração por pessoa jurídica em relação à sociedade em nome coletivo e em relação à sociedade em comandita, o fez de forma explícita. ${ }^{13}$

Os administradores podem ser designados no contrato social ou em ato separado, impondo-se ao administrador nomeado em ato separado que seja investido no cargo mediante termo de posse no livro de atas da administração, com a averbação de sua nomeação no registro competente, em dez dias da investidura, mencionando-se sua qualificação pessoal, data da nomeação e prazo da gestão. Tais providências permitirão maior transparência, possibilitando-se aos que tenham relações com a sociedade tomar conhecimento, com exatidão, de quem se reveste da condição de administrador e por quanto tempo.

Uma ou mais pessoas podem administrar a sociedade limitada, compete aos sócios, no contrato social, definir o perfil de administração que pretendem para a sociedade limitada, sendo certo que nas sociedades limitadas de feição personalista a administração tende a ser realizada por poucas pessoas, em regra sócios, sem a especialização de funções, ao passo que nas sociedades limitadas de perfil capitalista a administração tende a ser realizada por muitas pessoas, em regra estranhas ao quadro societário, com especialização das funções da gestão. A administração pode ser exercida de forma conjunta ou separadamente, quando forem vários os administradores. Tais aspectos repercutem na responsabilidade dos administradores.

\footnotetext{
${ }^{11}$ CARVAlhosa, Modesto, Comentários ao Código Civil: parte especial - do direito de empresa. In: AZEVEDO, Antônio Junqueira (Coord.). São Paulo: Saraiva, 2003. v.13., p.110.

${ }^{12}$ GONÇALVES NETO, Alfredo de Assis, op. cit., 2007, p.329: "A fórmula de gestão por pessoa jurídica não é nefasta nem deve ser eliminada, porquanto amplamente utilizada por sociedades limitadas, principalmente estrangeiras, e razão de o patrimônio da administradora garantir os atos de gestão da pessoa natural por ela designada para o exercício da função. Se isso vinha dando certo, não há razão para dar ás disposições do Código Civil uma interpretação no sentido de não permitir essa facilidade há tempo existente - interpretação, aliás, que insere em seu texto palavras que ele não contém".

13 "Artigo 1039 - Somente pessoas físicas podem tomar parte na sociedade em nome coletivo, respondendo todos os sócios, solidária e ilimitadamente, pelas obrigações sociais." "Artigo 1045 - Na sociedade em comandita simples tomam parte sócios de duas categorias: os comanditados, pessoas físicas, responsáveis solidária e ilimitadamente pelas obrigações sociais, e os comanditários, obrigados somente pelo valor de sua quota."
} 
Nas sociedades limitadas de caráter capitalista, nada impede a constituição de conselho de administração como órgão administrativo de deliberação colegiada, que pode ou não seguir o modelo previsto na Lei das Sociedades Anônimas. ${ }^{14}$ A previsão pode ser muito útil ao equilíbrio de interesses dos sócios.

De forma lamentável, a escolha dos administradores é vinculada a maiorias qualificadas, o que impede previsões contratuais que facultem a indicação de membros da administração por sócios minoritários.

O uso da firma ou denominação social é privativo dos administradores que tenham os necessários poderes, na forma do artigo 1064, do Código Civil. ${ }^{15}$

Importante regra, inovadora em relação ao regime anterior, consta do parágrafo único, do artigo 1060, do Código Civil, ${ }^{16}$ que define que, atribuída a administração a todos os sócios, não se estende aos que posteriormente adquiriram essa qualidade, evitando-se que a transmissão da quota acarrete, também, a transmissão da condição de administrador. ${ }^{17}$

A regra torna conveniente que o contrato social defina o nome dos administradores, com respectivas atribuições e poderes. Caso ocorra o ingresso de novo sócio, impõe-se que seja disciplinada a sua condição de administrador ou não.

Caso o contrato social seja omisso em relação aos poderes dos administradores, entende-se que podem praticar todos os atos pertinentes à gestão da sociedade, com exceção da oneração ou alienação de bens imóveis, que depende da deliberação majoritária, a não ser que tais operações constituam o objeto social da empresa, na

\footnotetext{
${ }^{14}$ No mesmo sentido: "Sendo livre o ajuste entre os sócios nesse particular, não é necessário que o Conselho de Administração seja sempre integrado por sócios - o que era indispensável no domínio do Decreto 3.708/19, pela exigência de todos os administradores serem sócios. Torna-se possível, assim, a presença de estranhos no referido conselho, quando criado, salvo se o contrato social limitar-se a determinar a aplicação das disposições da Lei das Sociedades por Ações que exigem, para sua composição, a qualidade de acionista (artigo 146, da Lei 6.404/76)". GONÇALVES NETO, Alfredo de Assis, op. cit., 2007, p.327. O autor defende que possa participar do conselho de administração da sociedade limitada pessoa jurídica, posição da qual se discorda, o membro do conselho de administração é administrador e, como tal, deve ser pessoa natural, como anteriormente defendido.

15 “Artigo 1064 - O uso da firma ou denominação social é privativo dos administradores que tenham os necessários poderes."

16 “Artigo 1060 [...] Parágrafo único - A administração atribuída no contrato a todos os sócios não se estende de pleno direito aos que posteriormente adquiram essa qualidade".

${ }^{17}$ CORRÊA-LIMA, Osmar Brina. Sociedade limitada. Rio de Janeiro: Forense, 2006, p.58. O autor observa que: "Distinguem-se as qualidades de administrador e de cotista. O cotista pode, ou não, ser administrador da sociedade limitada; o administrador da sociedade limitada pode, ou não, ser cotista dela (v.o artigo 10610, O fato de alguém adquirir cotas de uma sociedade limitada não lhe atribui, ipso facto, a qualidade de administrador dessa sociedade. Ninguém pode tornar-se administrador contra a sua vontade".
} 
forma prevista no caput, do artigo 1015, aplicado às sociedades limitadas por força do artigo 1053, ambos do Código Civil. ${ }^{18}$

Quanto aos deveres do administrador em relação à sociedade limitada, no regime anterior não havia qualquer previsão sobre os deveres do administrador, lacuna que pode ser explicada pelo caráter contratualista da legislação pretérita e pela exigência de necessário vínculo entre a condição de sócio e a de administrador. Às sociedades limitadas de perfil capitalista, eram aplicadas as normas do anonimato, pela aplicação do artigo 18 do Decreto 3.708/19.

No direito acionário, existe vasta doutrina que analisa os direitos e deveres atribuídos aos administradores, que assumem importante função como instrumento para mitigar os conflitos de agência, entre os quais, se destacam o dever de diligência; o de cumprimento das finalidades da sociedade; o de lealdade; o de evitar situações de conflitos de interesses; e o de informar. ${ }^{19} 20$

No regime do Código Civil de 2002, no artigo 1011, aplicado às sociedades limitadas por força do artigo 1052, dispõe-se: "O administrador da sociedade deverá ter, no exercício de suas funções, o cuidado e a diligência que todo homem ativo e probo costuma empregar na administração de seus próprios negócios", tornando explícita a exigência dos deveres de cuidado e diligência em seu âmbito, seja o administrador sócio ou não. ${ }^{21} 22$

\footnotetext{
18 "Artigo 1015 - No silêncio do contrato, os administradores podem praticar todos os atos pertinentes á gestão da sociedade; não constituindo objeto social, a oneração ou a venda de bens imóveis depende do que a maioria dos sócios decidir".

${ }^{19}$ Estes os deveres indicados nos artigos 153 a 157 da Lei das Sociedades Anônimas, sendo ainda indicados outros deveres em artigos específicos como os descritos, por exemplo, nos artigos 123; 133; 134; 176; 244 e 273. Ao lado de todos eles, ainda podem ser indicados os deveres genéricos, decorrentes de normas gerais e do sistema societário brasileiro, os deveres de observar os estatutos cumprir as deliberações dos órgãos societários hierarquicamente superiores; controlar a atuação dos demais administradores e o de não competir com a sociedade.

${ }^{20}$ Ver sobre a matéria: PARENTE, Flávia. O dever de diligência dos administradores de sociedades anônimas. Rio de Janeiro: Renovar, 2005; NEVES, Vanessa Ramalhete Santos. Responsabilidade dos administradores de sociedades anônimas. Rio de Janeiro: Lumen Júris, 2002; RIBEIRO, Renato Ventura. Dever de diligência dos administradores de sociedades. São Paulo: Quartier Latin, 2006; TOLEDO, Paulo Fernando Campos Salles. O conselho de administração na sociedade anônima. São Paulo: Atlas, 1997; SIMÕES, Paula Cristina Raposo Rodrigues Cabriz. Os deveres de diligência e de lealdade dos administradores das sociedades anônimas. Lisboa, 1998. Dissertação (Mestrado em Ciências Jurídicas). Universidade Católica Portuguesa, 1998; SCHOLASTIQUE, Estelle. Le devoir de diligence des administateurs des sociétés. Droit français et anglais. Paris: LGDJ, 1998; PAES, Paulo Roberto Tavares. Responsabilidade de administradores de sociedades. São Paulo: RT, 1997; MAJÓ, J. O. Llebot. Los deberes de los administradores em la socieda anônima. Madrid: Civitas, 1996; ECHEGARAY, José Luis Diez. La responsabilidad civil de los administradores de la sociedad anônima. Madrid: Montecorvo, 1995.

${ }^{21}$ A redação é repetição da previsão do artigo 153, da Lei 6.404/76: "O administrador da companhia deve empregar, no exercício de suas funções, o cuidado e diligência que todo homem ativo e probo costuma empregar na administração dos seus próprios negócios".
} 
Esclareça-se, por oportuno, que o modelo clássico de compreensão do dever de diligência, paradigma do bom pai de família, está inteiramente superado. ${ }^{23}$ Atualmente, ser diligente é atuar em conformidade com as regras técnicas de administração, o que recomenda a modificação da regra legal prevista no direito nacional. ${ }^{24} 25$

A atuação técnica, profissional, deve ser direcionada ao alcance dos objetivos da sociedade, que configuram os limites da discricionariedade do administrador. ${ }^{26}$

É nesse sentido que prevê o artigo 1017, caput, do Código Civil: “o administrador que, sem consentimento escrito dos sócios, aplicar créditos ou bens em proveito próprio ou de terceiros, terá de restituí-los à sociedade, ou pagar o equivalente, com todos os lucros resultantes e, se houver prejuízo, por ele também, responderá".

A vontade da maioria também conforma os limites de atuação discricionária do administrador, sendo previsto no artigo 1013, parágrafo $2^{\circ}$, do Código Civil, que

\footnotetext{
${ }^{22}$ No parágrafo segundo, do aludido dispositivo, há referência à aplicação das disposições concernentes ao mandato às atividades do administrador. O que ressai inapropriado, como expõe, Flávia Parente: “[...] é inoportuna a menção ao instituto do mandato contida no parágrafo $2^{\circ}$, do artigo 1010, do Código Civil, uma vez que já está superada, no direito brasileiro, a teoria contratualista para explicar a relação jurídica existente entre a sociedade e seus administradores". PARENTE, Flávia. O dever de diligência dos administradores das sociedades anônimas. Rio de Janeiro: Renovar, 2005, p.53. Destaque-se que a regra também é contraditória com a previsão de responsabilidade por culpa, prevista no artigo 1016, do mesmo Código Civil.

${ }^{23}$ O Código de Sociedades Comerciais de Portugal dispõe: "Artigo 64 (dever de diligência) - Os gerentes, administradores ou diretores de uma sociedade devem actuar com a diligência de um gestor criterioso e ordenado, no interesse da sociedade, tendo em conta os interesses dos sócios e dos trabalhadores". O critério não é mais do bom pai de família, mas do bom homem de negócios.

24 Defendendo a superação do paradigma do bom pai de família: BULGARELLI, Waldírio. Apontamentos sobre a responsabilidade dos administradores das companhias. Revista de Direito Mercantil, Industrial, Econômico, Financeiro - RDM, São Paulo: Malheiros, n.50, p.75-105, 1983. Em sentido contrário RIBEIRO, Renato Ventura. Dever de diligência dos administradores de sociedades. São Paulo: Quartier Latin, 2006, p.246, para quem, “[...] a melhor interpretação é da análise do caso concreto. Se o administrador não é profissional, sua conduta deve ser apurada com base no padrão do homem médio, do bom pai de família. Sendo administrador profissional, deve ser exigida a diligência de "um homem de negócios".

${ }^{25}$ Atente-se que configura ato de abuso do poder de controle a indicação de administradores sabidamente inaptos, técnica ou moralmente, na forma prevista na letra d, do parágrafo $1^{\circ}$, do artigo 117 , da Lei 6.404/76, o que demonstra contradição com a admissão absoluta do critério do "bom pai de família". Também é demonstração da necessidade de capacitação técnica a regra do artigo 152, da aludida Lei, que estipula, no caput, que "A assembléia geral fixará o montante global ou individual da remuneração dos administradores, inclusive benefícios de qualquer natureza e verbas de representação, tendo em conta suas responsabilidades, o tempo dedicado às suas funções, sua competência e reputação profissional e o valor dos seus serviços no mercado".

${ }^{26}$ ZANINI, Carlos Klein. A doutrina dos fiduciary duties no direito norte-americano e a tutela das sociedades e acionistas minoritários frente aos administradores das sociedades anônimas. Revista de Direito Mercantil, Industrial, Econômico e Financeiro - RDM, São Paulo: Malheiros (Nova Série), ano XXXVI, v.109, p.134-145, jan./mar. 1998. Sobre a vinculação entre o objeto e interesse social, ver: BERTACCHINI, Elisabeta. Oggeto sociale e interesse tutelato nelle società per azioni. Milão: Giuffrè, 1995; ZANELLI, Enrico. La nozione di oggetto sociale. Milão: Giuffrè, 1962; LA VILLA, Gianluca. L'oggeto sociale. Milão: Giuffrè, 1974 e ALBIZA, Juan Carlos Saenz Garcia de. El objeto social em La sociedad anônima. Madrid: Editorial Civitas, 1990.
}

Revista Brasileira de Direito Empresarial -le-SSN: 2526-0235| Curitiba | v. 2 | n. 2 | p. 24 -41 | Jul/Dez. 2016. 
"responde por perdas e danos perante a sociedade o administrador que realizar operações, sabendo ou devendo saber que estava agindo em desacordo com a maioria".

Assim, o administrador que extrapolar os limites da discricionariedade estabelecidos pelo interesse social, utilizando-se de bens e créditos da sociedade, em benefício pessoal ou de terceiros, deverá restituí-los à sociedade e indenizar os prejuízos causados, bem como responderá por perdas e danos o administrador que realizar operações em desacordo com a maioria.

Decorrem do dever de diligência, ainda, os deveres correlatos de se qualificar para o exercício do cargo; o dever de obter todas as informações para o bom desempenho da função de administrador; o dever de investigar as informações recebidas, checar se são confiáveis e se podem embasar a tomada de decisões; e o dever de vigiar, que impõe aos administradores o dever de controlar as atividades desenvolvidas. ${ }^{27}$

A condição de administrador, seja sócio ou não, pressupõe ainda o atendimento a alguns pressupostos legais, entre eles, a não condenação a pena que vede, mesmo que temporariamente, o acesso a cargos públicos; ou por crime falimentar, de prevaricação, peita ou suborno, concussão, peculato; ou contra a economia popular, contra o sistema financeiro nacional, contra as normas de defesa da concorrência, contra as relações de consumo, a fé pública ou a propriedade, enquanto perdurarem os efeitos da condenação. Também não podem ser administradores as pessoas impedidas por lei especial, na forma do artigo 1011, parágrafo primeiro.

A disciplina da administração da sociedade limitada, considerando que ao administrador compete realizar o objeto social, configura proteção à empresa e, também, aos sócios minoritários. São firmadas regras que possibilitam a transparência dos atos de gestão e que vinculam a atuação dos administradores aos interesses sociais, ensejando uma administração desvinculada apenas dos interesses dos sócios majoritários.

\section{A PROFISSIONALIZAÇÃO DA GESTÃO E OS CONFLITOS DE AGÊNCIA}

No artigo 1061 do Código Civil, é admitida a possibilidade da administração da sociedade por terceiros alheios ao quadro societário, sendo estabelecida nítida distinção entre a condição de sócio e a de administrador. ${ }^{28}$

Por meio de tal dispositivo, caso queiram os sócios, é formalizada a separação entre a condição de majoritário (proprietário da maior quantidade de quotas) e a administração

\footnotetext{
${ }^{27}$ PARENTE, Flávia. O dever de diligência dos administradores das sociedades anônimas. Rio de Janeiro: Renovar, 2005, p.101-102.

${ }^{28}$ A doutrina recebe com otimismo a modificação legislativa: COELHO, Fábio Ulhôa. A sociedade limitada no novo Código Civil. São Paulo: Saraiva, 2003; FÁZIO JÚNIO, Waldo. Sociedades limitadas. São Paulo: Atlas, 2003 e CAMPOS FILHO, Moacyr Lobato. Sociedade de responsabilidade limitada. In: BERALDO, Leonardo de Faria (Org.). Direito societário na atualidade - aspectos polêmicos. Belo Horizonte: Del Rey, 2007.
}

Revista Brasileira de Direito Empresarial -le-SSN: 2526-0235| Curitiba | v. 2 | n. 2 | p. 24 - 41 | Jul/Dez. 2016. 
(gestão da empresa), tema já muito explorado pelos doutrinadores no âmbito da sociedade anônima, desde a clássica obra dos americanos Berle e Means. ${ }^{29}$

Dispõe o aludido artigo que, se o contrato permitir administradores não sócios, a designação deles dependerá de aprovação da unanimidade dos sócios, enquanto o capital não estiver integralizado, e de sócios representativos de $2 / 3$ (dois terços) do capital social, no mínimo, caso o capital já esteja integralizado.

Embora vinculada à unanimidade ou à expressiva maioria, o que pode dificultar a sua aprovação, a possibilidade de escolha de administrador não pertencente ao quadro societário inova na sociedade limitada. Historicamente, como visto, a administração da sociedade limitada era realizada por um de seus sócios, sendo admitida apenas a delegação de poderes, hipótese em que o delegante respondia, de forma ilimitada e solidária, pelos atos praticados pelo delegado. Agora, faculta-se a terceiro a efetiva administração da sociedade, com poderes próprios, não havendo responsabilização direta dos sócios pelos atos do administrador.

A novidade, ao mesmo tempo em que permite a profissionalização da gestão da empresa, insere no âmbito da sociedade limitada a discussão sobre conflitos de agência, então inexistente. ${ }^{30}$

Toda a teoria acerca dos conflitos de agência foi construída à luz das normas de regência da sociedade anônima, muita vez tendo por base modelos de governança típicos de países com estrutura de repartição de capital e nível de desenvolvimento inteiramente diverso do modelo brasileiro. Deve ser considerado que no Brasil, em razão da grande concentração de capital, os conflitos de agência são postos com freqüência entre acionista controlador e acionista minoritário. Certamente, a mesma realidade de concentração ocorre na sociedade limitada, fazendo com que despontem conflitos de agência entre majoritários e minoritários.

Entretanto, não há como negar a existência de tais conflitos no seio da sociedade limitada, no sentido de que:

os interesses daquele que administra a propriedade nem sempre estão alinhados com os de seu titular. São problemas de assimetria de informações entre agente e principal; preocupações em monitorar o comportamento do agente, garantindo que sua atuação se

\footnotetext{
${ }^{29}$ BERLE JR.; MEANS, Gardiner. A moderna sociedade anônima e a propriedade privada. Tradução de Dinah de Abreu Azeredo. São Paulo: Abril, 1984.

${ }^{30}$ JENSEN, Michael C.; MECKLING, William H. Theory of the firm: managerial behavior, agency cost and ownership structure. Journal of Financial Economics, New York, n.3, 1976, p.305-360.
}

Revista Brasileira de Direito Empresarial -le-SSN: 2526-0235| Curitiba | v. 2 | n. 2 | p. 24 -41 | Jul/Dez. 2016. 
dará de acordo com os interesses do principal; formas de incentivo de sua atuação, entre outros. $^{31}$

A opção pela gestão profissionalizada é mais compatível com a sociedade limitada capitalista, moldada sob as normas da sociedade anônima, em que o princípio da heteroorganicidade já está consagrado e os deveres dos administradores bem delineados.

A atribuição de deveres específicos aos administradores atua como instrumento para a mitigação dos conflitos de agência e, portanto, realiza a função de equilibrar os diversos interesses em seu contexto presentes.

\section{CONFLITO DE INTERESSES ENTRE O ADMINISTRADOR E A SOCIEDADE}

O conflito de interesses entre sócio e a sociedade limitada possui dupla regulação, a previsão do artigo 1074, parágrafo $2^{\circ}$, que estabelece regra de conflito formal, e a regra do artigo 1010, parágrafo $3^{\circ}$, aplicada à sociedade limitada por força do caput, do artigo 1072, todos do Código Civil, que estabelece regra de conflito material, o que será abordado em tópico específico.

Quanto ao conflito que envolve a sociedade e o administrador, no âmbito do capítulo específico das sociedades limitadas o regramento específico é precário, sendo necessário, em razão da exegese do artigo 1053, do Código Civil, caracterizado o perfil capitalista ou personalista da sociedade, optar pela aplicação das regras do artigo 156 da Lei 6.404/76 ou do artigo 1017 do Código Civil de 2002.

As hipóteses são bastante diferenciadas. Na forma do artigo 156, da Lei das Sociedades Anônimas, é firmada regra de conflito formal de interesses, ${ }^{32}$ ao passo que o molde previsto no artigo 1017 do Código Civil estabelece conflito material de interesses. A disposição do artigo 156 prevê que " é vedado ao administrador intervir em qualquer operação social em que tiver interesse conflitante com o da companhia, bem como na deliberação que a respeito tomarem os demais administradores, cumprindo-lhe cientificá-los do seu impedimento e fazer consignar, em ata da reunião do Conselho de Administração ou da Diretoria, a natureza e extensão de seu interesse".

Trata-se de regra de conflito formal, que impõe a impossibilidade de atuação do administrador, em qualquer operação ou deliberação social, por presunção anterior de

\footnotetext{
${ }^{31}$ SANTOS, Aline de Menezes. Reflexões sobre governança corporativa no Brasil. Revista de Direito Mercantil, Industrial, Econômico e Financeiro - RDM, São Paulo: Malheiros (Nova Série), n.130, p.180-206, abr./jun. 2003, p.186.

${ }^{32}$ LOBO, Carlos Augusto da Silveira. Conflito de interesses entre a companhia e seu administrador. Revista de Direito Renovar, Rio de Janeiro, v.39, p.83-95, set./dez. 2007.
} 
prejuízo, sendo-lhe imposto que manifeste seu impedimento, a natureza e extensão do interesse. $^{33}$

Observe-se que o dispositivo em exame não é impeditivo da realização do negócio entre a sociedade e os administradores, como era previsto na antiga regência do anonimato. ${ }^{34}$ Abstendo-se de gerir ou de deliberar, pode o administrador contratar com a sociedade, desde que, evidentemente, seja a matéria aprovada por deliberação dos demais administradores, contudo, a contratação, obrigatoriamente, tem que ocorrer em condições eqüitativas, ou seja, idênticas às que ocorreriam no mercado ou que seriam contratadas com terceiros.

Protege-se, desta forma, o interesse social ${ }^{35}$ e, por consequiência, os sócios minoritários das sociedades limitadas de perfil capitalista, muitas vezes alheios à administração da empresa.

Nas sociedades limitadas de perfil personalista, regidas subsidiariamente pelas regras das sociedades simples, duas regras limitam a atuação da administração em conflitos com a sociedade, a regra do parágrafo $2^{\circ}$, do artigo 1013, que estipula que o administrador responde por perdas e danos perante a sociedade quando realizar operações, sabendo ou devendo saber, em desacordo com a maioria e o caput do artigo 1017, ambos do Código Civil, referente à utilização indevida de bens ou créditos.

A característica das sociedades limitadas personalistas, formadas por poucos sócios, unidos pela affectio societatis, responsáveis pelo aporte de recursos e pela gestão da sociedade, termina por flexibilizar as ponderações sobre a restrição dos poderes de representação dos administradores, fazendo com que não seja previamente vedada a contratação com a sociedade, mas apurado, no caso concreto, o prejuízo à sociedade.

Quanto às deliberações, no artigo 1017, parágrafo único, do Código Civil, prevê-se que "fica sujeito a sanções o administrador que, tendo em qualquer operação interesse contrário ao da sociedade, tome parte na correspondente deliberação".

O aludido dispositivo sujeita a sanções o administrador que tenha interesse contrário ao da sociedade e tome parte das deliberações que o concretizem. Trata-se de regra de

\footnotetext{
${ }^{33}$ CARVAlHOSA, Modesto. Comentários à Lei de Sociedades Anônimas. São Paulo: Saraiva, 1998. v.3. p.273.

${ }^{34}$ Decreto-Lei 2627/1940, artigo 120 - "É vedado ao diretor intervir em qualquer operação social em que tenha interesse oposto ao da companhia, bem como na deliberação que a respeito tomarem os demais diretores, cumprindo-lhe cientificá-los do seu impedimento. Parágrafo único - A violação dessa proibição sujeitará o diretor à responsabilidade civil, pelos prejuízos causados à sociedade e à responsabilidade penal que no caso couber".

${ }^{35}$ Neste sentido é que o artigo 153, da Lei 6.404/76, dispõe: "O administrador deve exercer as atribuições que a lei e o estatuto lhe conferem para lograr os fins e no interesse da companhia, satisfeitas as exigências do bem público e da função social da empresa”.
} 
conflito material, em que a contrariedade de interesses não é pressuposta, sendo apurada em cada caso concreto e sujeita a sanções.

O dispositivo é aberto, porque não delimita as sanções a que está submetido o administrador que atua em conflito de interesses, mas, certamente, as sanções devem ser fortes o suficiente para reparar os danos causados à sociedade e coibir a repetição da atuação desconforme.

Além das sanções pertinentes ao caso, a prática de atos em conflito de interesse pode significar quebra de confiança na atuação do gestor, ensejando a sua destituição. A este propósito, o artigo 1063 dispõe que o exercício do cargo de administrador cessa pela destituição, a qualquer tempo, do titular, desde que essa seja a vontade da maioria. ${ }^{36}$

Por conclusão, aponta-se que a composição de interesses entre os administradores e a sociedade limitada atende a diferenciados formatos, conforme seja a sociedade de caráter capitalista ou personalista.

Nas sociedades limitadas capitalistas, o conflito de interesses entre a sociedade e a administração é formal, o que implica na impossibilidade de prática do ato de administração ou da manifestação administrativa que, caso realizados, são reputados nulos.

A conseqüência da previsão do conflito material nas sociedades limitadas personalistas é que pode ser imposto o dever de indenizar a sociedade prejudicada, mas não se permite a anulação do ato de gestão ou da deliberação administrativa.

Regra genérica de conflito de interesses entre os administradores e a sociedade, aplicada às sociedades limitadas de perfil capitalista ou personalista, é a firmada no parágrafo $2^{\circ}$, do artigo $1078,{ }^{37}$ que veda a participação do administrador na votação de suas contas, evidentemente considerando a hipótese em que ele também seja sócio. Descabido seria permitir ao sócio administrador a participação na votação acerca de suas contas, o que comprometeria, seriamente, os interesses dos sócios minoritários e, em último grau, da própria sociedade. A regra, no entanto, não se aplica à hipótese em que todos os sócios sejam administradores.

\section{A FISCALIZAÇÃO DOS ATOS DA ADMINISTRAÇÃO}

Aos sócios da sociedade limitada é assegurado o direito de fiscalizar a gestão dos negócios, podendo, a qualquer tempo, examinar os livros e documentos e o estado da caixa e da carteira da sociedade, salvo estipulação contratual que estabeleça época

\footnotetext{
${ }^{36}$ Ver quoruns fixados nos artigos 1061 e parágrafo $1^{\circ}$, do artigo 1063 , do Código Civil.

37 “Artigo 1078 - [...] Parágrafo $2^{\circ}$ - Instalada a assembléia, proceder-se-á à leitura dos documentos referidos no parágrafo antecedente, os quais serão submetidos, pelo presidente, a discussão e votação, nesta não podendo tomar parte os membros da administração e, se houver, os do conselho fiscal”.
}

Revista Brasileira de Direito Empresarial -le-SSN: 2526-0235| Curitiba | v. 2 | n. 2 | p. 24 - 41 | Jul/Dez. 2016. 
própria, conforme assegurado pelo artigo 1021, do Código Civil, aplicado às sociedades limitadas por força do artigo 1053, do mesmo diploma legal.

Eleitos os administradores, exclusivamente, pelo princípio majoritário, já que na regência da sociedade limitada não há previsão de eleição em separado de administradores pelos sócios minoritários, o que não lhes possibilita representação nos órgãos da administração, a não ser por estipulação contratual, torna-se a fiscalização importante instrumento de preservação dos interesses dos mesmos, o que evidencia a importância do dispositivo antes referido.

Já no regime do Decreto 3.708/19 havia a compreensão exata da importância do direito de fiscalização dos atos da administração, embora o mesmo não fizesse qualquer referência ao aludido direito. ${ }^{38}$

Omisso o contrato social, a fundamentação para o exercício do direito de fiscalização decorria, além do princípio geral de prestação de contas, das disposições do Código Comercial de 1850 ou da Lei das Sociedades Anônimas. ${ }^{39}$

No regime do Código Civil, a matéria é melhor disciplinada. Além de ser assegurado aos sócios examinar os livros e documentos e o estado da caixa e da carteira da sociedade, a qualquer tempo, se no contrato não for estipulada época própria, exige-se a elaboração, ao término de cada exercício social, do inventário, do balanço patrimonial e do balanço de resultado econômico, com previsto no artigo 1065, do Código Civil. ${ }^{40}$ Embora não seja expressa a imputação, é aos administradores que cabe a obrigação, por serem os responsáveis pela elaboração dos documentos em exame.

Também é previsto no Código Civil regramento próprio sobre a escrituração das sociedades em geral e, por conseqüência, das sociedades limitadas, narrado nos artigos 1.179 a $1.195 .^{41}$ Destaquem-se, entretanto, as disposições da Lei 11.638 , de 28 de dezembro de 2007, cuja entrada em vigor se deu em $1^{\circ}$ de janeiro de 2008 , que altera dispositivos da Lei 6.404/76 e da Lei 6385/76, e estende às sociedades de grande porte regras relativas à elaboração e divulgação de demonstrações financeiras. Na forma do artigo $3^{\circ}$, dispõe-se que se aplicam às sociedades de grande porte, constituídas sob qualquer formato, as disposições da Lei 6.404, de 15 de dezembro de 1976, sobre escrituração e elaboração de demonstrações financeiras e a obrigatoriedade de auditoria independente por auditor registrado na Comissão de Valores Mobiliários - CVM.

\footnotetext{
${ }^{38}$ CARVALHOSA, Modesto. Parte especial do direito de empresa. In: AZEVEDO, Antônio Junqueira de. (Org.). Comentários ao Código Civil. São Paulo: Saraiva, 2003. v.13, p.142-143.

${ }^{39}$ GONÇALVES NETO, Alfredo de Assis. Direito da empresa - comentários aos artigos 966 a 1.195 do Código Civil. São Paulo: Revista dos Tribunais, 2007, p.377.

${ }^{40}$ SIMÃ̃O FILHO, Adalberto. A nova sociedade limitada. São Paulo: Manole, 2004.

${ }^{41}$ CARVALHOSA, Modesto, op. cit., 2003, p.144-145.
} 
A proteção dos minoritários se complementa pela necessidade de aprovação das contas em assembléia anual, conforme narrado no artigo 1078 do Código Civil. Dispõe o aludido artigo que, pelo menos uma vez por ano, deve realizar-se assembléia de sócios, nos quatro meses que se seguem ao fim do exercício social, com a finalidade de tomar as contas dos administradores e deliberar sobre o balanço patrimonial e o de resultado econômico e, ainda, para designar administradores, se for o caso e tratar de qualquer outro assunto, constante da ordem do dia. Não é compreensível a dispensa de deliberação sobre o inventário, demonstração financeira obrigatória também prevista no artigo 1065 do Código Civil.

Embora o quórum de aprovação das contas seja reduzido, referente aos sócios representantes da maioria do capital social presente ao ato deliberativo, como previsto no artigo 1076, III, do Código Civil, trata-se a assembléia de eficaz instrumento de participação e controle dos negócios da administração pelos sócios minoritários.

Obriga-se que, até trinta dias antes da data da assembléia ou reunião, sejam disponibilizados aos sócios que não exerçam a administração, por escrito e com a prova do respectivo recebimento, o balanço patrimonial e o de resultado econômico, democratizando o acesso às demonstrações financeiras e permitindo a sua análise técnica.

A aprovação, sem reserva, do balanço patrimonial e do de resultado econômico, salvo erro, dolo ou simulação, exonera de responsabilidade os membros da administração e, caso exista, os do conselho fiscal. A exoneração de responsabilidade é ato interno, não diz respeito à responsabilidade do administrador perante terceiros, mas sim perante a própria sociedade que, uma vez aprovando as contas dos administradores, não poderá deles se ressarcir, como decorre do artigo 1078, parágrafo $3^{\circ}$.

$\mathrm{Na}$ forma do parágrafo $4^{\circ}$, do aludido dispositivo, o direito de anulação da deliberação de aprovação das contas, por ocorrência de vícios, prescreve em dois anos. Após, resta consolidada a aprovação.

Prevê o Código Civil a possibilidade de instalação de conselho fiscal, como órgão auxiliar de fiscalização da administração, sem prejuízo dos poderes da assembléia, como previsto no artigo 1066 do Código Civil. Deve ser composto por três ou mais membros e respectivos suplentes, sócios ou não, obrigatoriamente residentes no país, eleitos na assembléia anual, por mandatos anuais. Dele não podem fazer parte os inelegíveis enumerados no parágrafo $1^{\circ}$ do artigo 1011 do Código Civil, os membros dos demais órgãos da sociedade ou de outra por ela controlada, os empregados de quaisquer delas ou dos respectivos administradores, o cônjuge ou parente destes até o terceiro grau. 
A doutrina não é unânime quanto aos benefícios da regulação específica do conselho fiscal no regramento da sociedade limitada, ${ }^{42}$ no entanto, compreende-se que há mais benéficos do que malefícios na regulação, com a melhora do sistema de fiscalização da administração nas sociedades limitadas.

A constituição de conselho fiscal impede que suas atribuições e poderes, conferidos por lei, sejam outorgados a outro órgão da sociedade. Cabe ao conselho: (i) examinar, pelo menos trimestralmente, os livros e papéis da sociedade e o estado de caixa e da carteira, devendo os administradores ou liquidantes prestar-lhes as informações solicitadas; (ii) lavrar no livro de atas e pareceres o resultado dos exames antes referidos; (iii) exarar no mesmo livro e apresentar à assembléia anual dos sócios parecer sobre os negócios e as operações sociais do exercício em que servirem, tomando por base o balanço patrimonial e o de resultado econômico; (iv) denunciar erros, fraudes ou crimes que descobrirem, sugerindo providências úteis à sociedade; (v) convocar a assembléia dos sócios se a diretoria retardar por mais de trinta dias a sua convocação anual, ou sempre que ocorram motivos graves e urgentes; e (vi) praticar, durante o período da liquidação da sociedade, os atos a que se refere este artigo, tendo em vista as disposições especiais reguladoras da liquidação, conforme disposição do artigo 1069 do Código Civil.

A atuação do conselho pode ser forma de equilibrar o interesse na fiscalização da administração com a impossibilidade de a sociedade ter que ofertar seus livros, documentos, o estado da caixa e da carteira da sociedade, a qualquer sócio, a qualquer momento, quando não haja previsão contratual específica estabelecendo época própria, já que decorre do artigo 1069, inciso I, a realização do exame em período razoável, não superior a três meses. Tem-se por certo que, existindo conselho fiscal, o direito dos sócios de acesso às informações fica restrito, não mais sendo exercido como previsto no artigo 1021, sob pena de inviabilização do funcionamento da sociedade.

A regra de escolha em separado de um dos membros do conselho fiscal, e respectivo suplente, pelos sócios que representem, pelo menos, um quinto do capital social, importa apenas em ampliação da transparência da administração, facultando maior informação aos sócios minoritários, pois a diminuta representação não será determinante para os resultados da atuação do conselho. De qualquer forma, significa maior acesso aos dados da administração, o que enseja a ampliação da proteção dos interesses dos minoritários.

\section{CONCLUSÃO}

À guiza de conclusão, pode-se apontar, de forma geral, que A regência da sociedade limitada no Código Civil enseja o reconhecimento e proteção de interesses alheios aos

${ }^{42}$ CARVALHOSA, Modesto, op. cit., 2003, p.147-148. 
dos sócios. No âmbito interno, as normas de regência permitem a proteção ao sócio minoritário.

O exercício abusivo da administração pode ser meio de opressão aos sócios minoritários, impondo-se a fixação de regras que o impeça.

Aspectos da tipologia da administração da sociedade limitada permitem concluir que é mantida a liberdade de modulação da administração, contudo, diversas normas cogentes limitam o seu exercício abusivo.

Entre as consequências de tais normas, destacam-se:

(i) admite-se a profissionalização da gestão da sociedade limitada, com a eleição de administradores não sócios. Para se evitar conflitos de agência, são dispostas normas que ensejam o controle de adequação da atuação dos gestores, sendo certo que foi superado o modelo clássico de compreensão do dever de diligência, paradigma do bom pai de família, sendo atribuídos deveres específicos ao administrador;

(ii) o interesse social deve ser perseguido, como forma de proteção ao interesse dos minoritários, sendo coibido o conflito de interesses entre a administração e a sociedade;

(iii) assegura-se a ampla fiscalização da administração da sociedade pelos sócios, o que amplia a proteção aos minoritários. Os sócios podem, em caráter facultativo, constituir conselho fiscal para auxílio na função de fiscalização.

\section{REFERÊNCIAS BIBLIOGRÁFICAS}

ABRÃO, Nelson. Sociedade por quotas de responsabilidade limitada. 6. ed. Atualizada por Carlos Henrique Abrão. São Paulo: Revista dos Tribunais, 1988, p.121122.

ALBIZA, Juan Carlos Saenz Garcia de. El objeto social em La sociedad anônima. Madrid: Editorial Civitas, 1990.

BERLE JR.; MEANS, Gardiner. A moderna sociedade anônima e a propriedade privada. Tradução de Dinah de Abreu Azeredo. São Paulo: Abril, 1984.

BERTACCHINI, Elisabeta. Oggeto sociale e interesse tutelato nelle società per azioni. Milão: Giuffrè, 1995.

BULGARELLI, Waldírio. Apontamentos sobre a responsabilidade dos administradores das companhias. Revista de Direito Mercantil, Industrial, Econômico, Financeiro RDM, São Paulo: Malheiros, n.50, p.75-105, 1983.

Revista Brasileira de Direito Empresarial -le-SSN: 2526-0235| Curitiba | v. 2 | n. 2 | p. 24 - 41 | Jul/Dez. 2016. 
CAMPOS FILHO, Moacyr Lobato. Sociedade de responsabilidade limitada. In: BERALDO, Leonardo de Faria (Org.). Direito societário na atualidade - aspectos polêmicos. Belo Horizonte: Del Rey, 2007.

CARValhosA, Modesto. Comentários ao Código Civil: parte especial - do direito de empresa. In: AZEVEDO, Antônio Junqueira (Coord.). São Paulo: Saraiva, 2003. v.13.

COELHO, Fábio Ulhôa. A sociedade limitada no novo Código Civil. São Paulo: Saraiva, 2003; FÁZIO

CORRÊA-LIMA, Osmar Brina. Sociedade limitada. Rio de Janeiro: Forense, 2006.

ECHEGARAY, José Luis Diez. La responsabilidad civil de los administradores de la sociedad anônima. Madrid: Montecorvo, 1995.

GONÇALVES NETO, Alfredo de Assis. Direito de empresa - comentários aos artigos 966 a 1.195 do Código Civil. São Paulo: Revista dos Tribunais, 2007.

JENSEN, Michael C.; MECKLING, William H. Theory of the firm: managerial behavior, agency cost and ownership structure. Journal of Financial Economics, New York, n.3, 1976, p.305-360.

JÚNIOR, Waldo. Sociedades limitadas. São Paulo: Atlas, 2003

LA VILLA, Gianluca. L’oggeto sociale. Milão: Giuffrè, 1974

MAJÓ, J. O. Llebot. Los deberes de los administradores em la socieda anônima. Madrid: Civitas, 1996;

NEVES, Vanessa Ramalhete Santos. Responsabilidade dos administradores de sociedades anônimas. Rio de Janeiro: Lumen Júris, 2002.

PAES, Paulo Roberto Tavares. Responsabilidade de administradores de sociedades. São Paulo: RT, 1997.

PARENTE, Flávia. O dever de diligência dos administradores de sociedades anônimas. Rio de Janeiro: Renovar, 2005.

PEIXOTO, Carlos Fulgêncio da Cunha. A sociedade por quotas de responsabilidade limitada: doutrina, jurisprudência, legislação e prática. Rio de Janeiro: Forense, 1956. v.I.

PONTES DE MIRANDA, Francisco Cavalcante. Tratado de direito privado. 3. ed. Rio de Janeiro: Borsoi, 1977. v.10 e 49. t. I, p.282. 
TEIXEIRA, Egberto Lacerda. Das sociedades por quotas de responsabilidade limitada. Atualizado de acordo com o novo Código Civil por Silas Tozzini e, Renato Berger. São Paulo: Quartier Latin, 2006.

RIBEIRO, Renato Ventura. Dever de diligência dos administradores de sociedades. São Paulo: Quartier Latin, 2006.

SCHOLASTIQUE, Estelle. Le devoir de diligence des administateurs des sociétés. Droit français et anglais. Paris: LGDJ, 1998.

SANTOS, Aline de Menezes. Reflexões sobre governança corporativa no Brasil. Revista de Direito Mercantil, Industrial, Econômico e Financeiro - RDM, São Paulo: Malheiros (Nova Série), n.130, p.180-206, abr./jun. 2003.

SIMÃO FILHO, Adalberto. A nova sociedade limitada. São Paulo: Manole, 2004.

SIMÕES, Paula Cristina Raposo Rodrigues Cabriz. Os deveres de diligência e de lealdade dos administradores das sociedades anônimas. Lisboa, 1998. Dissertação (Mestrado em Ciências Jurídicas). Universidade Católica Portuguesa, 1998.

TOLEDO, Salles Paulo Fernando Campos. O conselho de administração na sociedade anônima. São Paulo: Atlas, 1997.

ZANELLI, Enrico. La nozione di oggetto sociale. Milão: Giuffrè, 1962.

ZANINI, Carlos Klein. A doutrina dos fiduciary duties no direito norte-americano e a tutela das sociedades e acionistas minoritários frente aos administradores das sociedades anônimas. Revista de Direito Mercantil, Industrial, Econômico e Financeiro - RDM, São Paulo: Malheiros (Nova Série), ano XXXVI, v.109, p.134-145, jan./mar. 1998. 